\title{
Regional and Seasonal Variation of Polycyclic Aromatic Hydrocarbons in Water and Mollusca at Quarna North of Shatt AL-Arab River
}

\author{
Eman A.AL-Talal Amar.A.Talal Hamid T. AL-Saad* \\ Department of Ecology-College of Science-Basrah University,Iraq. \\ *College of Marine Scince-Basrah university,Iraq
}

\begin{abstract}
Distribution and seasonal variations and sources of of the sixteen polycyclic aromatic hydrocarbons (PAHs) was studied in surface water and and fuor species of molluscs (Theodoxus Jordani, Melanoides taberculata Melanopsis nodosa, Bellamya bengalensis ) from three stations at Al-Quarna in Shatt Al Arab river during the low tide period from September, 2018 to March, 2019 . Liquid-liquid extraction was used for water samples, while PAHs in molluscs were extracted using Soxhlet Extraction and finally analyzed by means of gas chromatography. physical and chemical parameter were measured such as . Water Temperature range from $\left(13^{\circ} \mathrm{C}\right.$ to $\left.39^{\circ} \mathrm{C}\right)$, Dissolved oxygen range from $(6.5 \mathrm{mg} / \mathrm{l}$ to $3.84 \mathrm{mg} / \mathrm{l}), \mathrm{PH}$ range from (8.15-7.17) and Electrical conductivity (2.59 $\mathrm{ms} / \mathrm{cm}-4.75 \mathrm{~ms} / \mathrm{cm})$. Results of PAHs in water samples was ranged from $(1.4754 \mathrm{ng} / 1)$ during summer in the first station to $(3.4215 \mathrm{ng} / 1)$ during winter at the third station. While the total PAHs in molluscs range from $0.876 \mathrm{ng} / \mathrm{g}$ dry weight in the T.jordani in station 1during summer to $9.093 \mathrm{ng} / \mathrm{g}$ dry weight in the B.bengalensis during winter . The Highest concentration of PAHs in the four species were arranged as fellow :Bellamya bengalensis $>$ Melanopsis nodosa $>$ Melanoides taberculata $>$ Theodoxus Jordani. When we compares the concentration TPHs in water and molluscs with other study it allies within these concentration.
\end{abstract}

Keywords: PAH, water, Mollusca, Pollution,Qurna,ShattAL-Arab River,Basrah,Iraq

DOI: $10.7176 /$ JNSR/9-14-05

Publication date:July $31^{\text {st }} 2019$

\section{Introduction}

The condition and health of the aquatic environment is constantly being monitored so that the effects of pollution can be better understood and its impact reduced (1). The extent of contamination can be assessed by measuring pollutant concentrations in water, sediments and organic tissue samples. Although easier to process, water samples are difficult to interpret since the water is constantly flowing, transporting pollutants from one place to another while diluting them, often to concentrations below detection limits (2). One of the most dangerous pollutant for water environment is petroleum hydrocarbons and it's derivatives (3).only limited information is available on the fate of hydrocarbons in the Shatt Al-Arab river. An important route is the uptake and assimilation of these compounds by aquatic organisms in general and mollusca in particular(4). Molluscs are well known for their ability to accumulate hydrocarbons (and other pollutants) and have been employed as indicators of petroleum contamination in many parts of the world (5). Among petroleum hydrocarbon pollutants sixteen polycyclic aromatic hydrocarbons (PAHs) are listed as priority pollutants due to high stability in the environment $(6,7)$. Polycyclic aromatic hydrocarbons (PAHs), having two or more fused benzene rings, are a group of organic pollutants that occur widely in the environment (8) .

There are two origins of PAHs in the environment, natural and anthropogenic. The natural origin attributes to forest fires and volcanic activity, etc. (PAH background values). The anthropogenic one includes incomplete combustion of fossil fuels, and industrial emissions (PAH contamination levels) $(9,10)$. Aquatic environments are also polluted with PAHs through anthropogenic activities such as accidental oil spills, discharge from routine tanker operations, and municipal and urban runoff. Additionally they tend to accumulate preferentially in river and marine sediments rather than in air or water, due to their high hydrophobicity (11). Generally, PAHs are hydrophobic with very little solubility in water which decreases with increasing molecular weight or the number of fused aromatic rings. The high molecular weight (HMW) PAHs ( $\geq 4$ fused aromatic rings) are less water-soluble, less volatile and more lipophilic than lower molecular weight (LMW) PAHs ( $\leq 3$ fused aromatic rings) $(12,13,14)$ Due to their carcinogenic and mutagenic effects to both terrestrial and aquatic organisms, PAHs have attracted much attention (15).

Shatt Al-Arab River is the most important river in Iraq, because of its economical, social and ecological values. It is the main source of surface water in Basrah City, southern of Iraq. It's water has been used for various purposes including potable water supply, irrigation, fisheries, navigation, and industrial uses. Moreover, Shatt AlArab River is the prime fresh water source and pours about $5 \times 109 \mathrm{~m}^{3}$ nutrient rich water into the Arabian Gulf each year (16). The Shatt Al-Arab river are known to be severely polluted due to entry of both domestic sewage and industrial wastewater. The industrial effluents are derived from paper and fertilizer mills, electrical power 
stations, refined oil plants, petrochemical manufacture and other industries (17).

The aims of the present study are to determine the concentrations and source of Polycyclic Aromatic hydrocarbon fractions in water and mollusca, to give baseline data for further work.

\section{Materials and Methods:}

Study area and sampling sites:

The confluence of the Tigris and Euphrates rivers at the town of Qurna, north of Basra city forms the Shatt AlArab River, which flows to the south west to the Arabian Gulf. The Shatt Al-Arab River has a length of $200 \mathrm{~km}$, a width range between $400 \mathrm{~m}$ at Basra and up to more than $2 \mathrm{~km}$ at the estuary and a depth of between 8-15 m, considering tides $(18,19)$. This study was conducted during the period Spt. 2018 to Mar.,2019. Samples of water and four species of molluscs, (Theodoxus Jordani, Melanoides taberculata Melanopsis nodosa, Bellamya bengalensis) were collected from the three stations at Quarna in the northern of Shatt al-Arab(Figure 1). Water samples were collected at least $20-30 \mathrm{~cm}$ under the water surface and whenever it was possible at the middle of the river using dark glass bottles and preserved in situ with $25 \mathrm{ml}$. CCl4. Samples were never taken when it was raining, molluscs Samples were collected at least 350 adult individuals of uniform size of each species.

The tissues of the animals were pooled and macerated in a food liquidizer from which at least 3 replicates of $15 \mathrm{~g}$ each were freeze-dried, grounded and sieved through a $63 \mu$ metal sieve.

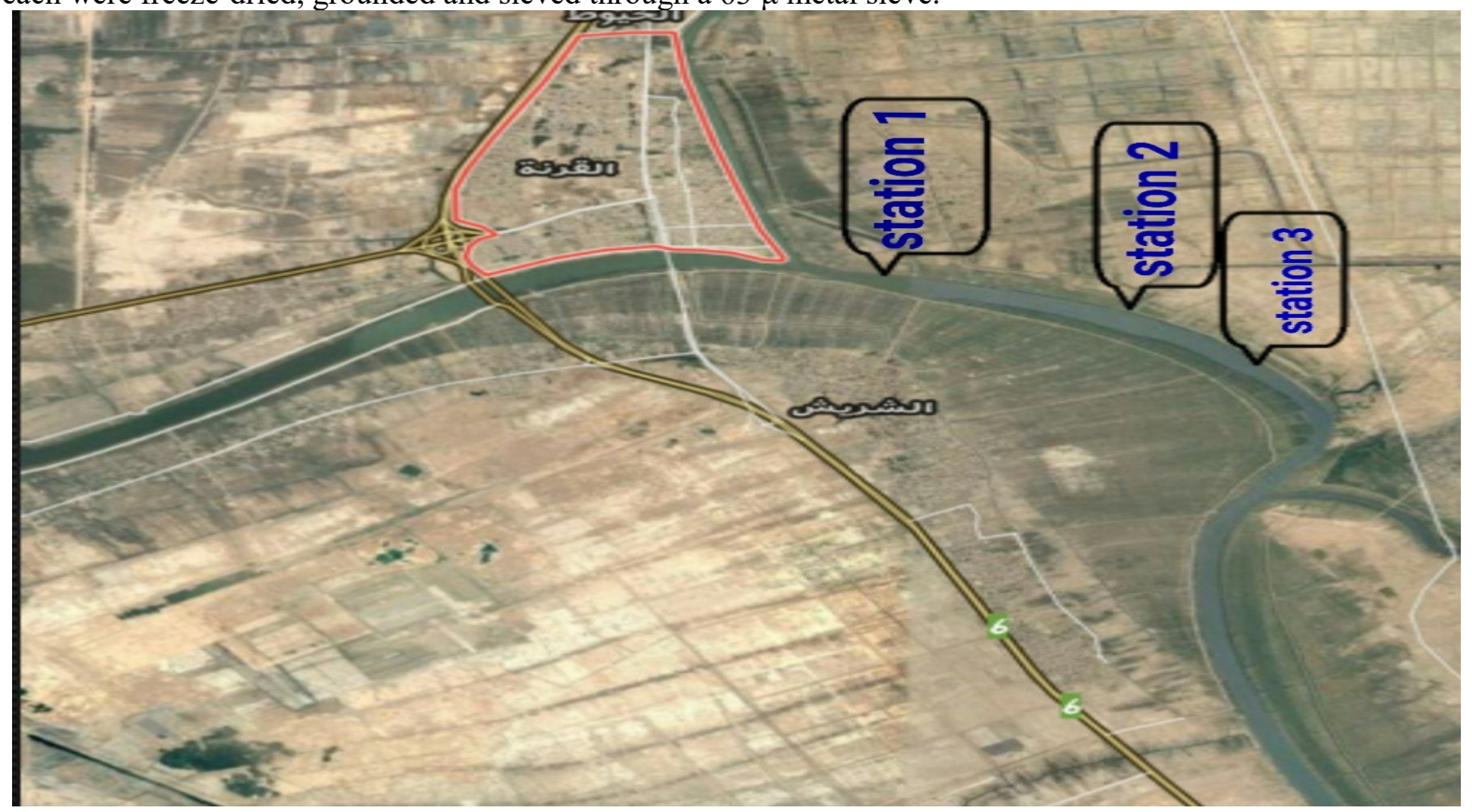

(Figure 1) Map of Shatt al-Arab River showing the three sampling stations.

\section{Environmental measurements:}

Water physical and chemical parameters including Dissolved oxygen (DO) and Water Temperature (WT), Electrical Conductivity (EC), and pH were measured insitu using the Multimeter type (Multi 350 i SET 5 ).

\section{Extraction of PAHs from water:}

Hydrocarbons in water sample (about 5L) were extracted according to (20) by mixing with another (25 ml ) CCl4 for $20 \mathrm{~min}$. using Water Mixer, the liquid fraction was drained, and the residual ( about 1L) was transferred into separator funnel. The organic (lower) phase was carefully poured into a glass column containing ( $5 \mathrm{~g}$ ) of anhydrous sodium sulfate (Na2SO4), collected and dried. The residual was dissolved with n-hexane (25 ml ), and passed through a $20 \mathrm{~cm}$ glass column ( packed with glass wool at the bottom, about $10 \mathrm{~g}$ deactivated silica gel (100-200 mesh), $10 \mathrm{~g}$ deactivated alumina ( 100-200 mesh), and $5 \mathrm{~g}$ anhydrous sodium sulfate (Na2SO4) at the top ). The aromatics were eluted with benzene $(25 \mathrm{ml})$. The samples dried and stored until detection with Gas-liquid chromatography (for Polycyclic aromatic hydrocarbons (PAHs) .

Helium used as carrier gas in liquid Gas Chromatography with linear velocity of $1 \mathrm{ml} . / \mathrm{min}$ and Flam Ionization Detector(FID) the operating temperatures for injector and detector were $300^{\circ} \mathrm{C}$ and $320^{\circ} \mathrm{C}$, respectively, and the column temperature was held at $50^{\circ} \mathrm{C}$ as initial temperature for $8 \mathrm{~min}$. then $8^{\circ} \mathrm{C} / \mathrm{min}$ to $350^{\circ} \mathrm{C}$.

\section{Extraction of PAHs from molluscs tissues:}

The procedure of (21) was used in the extraction of hydrocarbons from molluscs tissues. Ten grams of dried 
molluscs tissues were placed in a pre-extracted cellulose thimble and soxhlet extracted with $150 \mathrm{ml}$ methanol : benzene ( $1: 1$ ratio) for 24 - hours. The extract was then transferred into a storage flask. The sample was further extracted with a fresh solvent. The combined extracts were reduced in volume to ca $10 \mathrm{ml}$ in a rotary vacuum evaporator. They were then saponified for 2 - hours with a solution of $4 \mathrm{~N} \mathrm{KOH}$ in 1: 1 methanol: benzene. After extraction of the unsaponified matter with hexane, The sample is taken from the rotator and then placed on a chromatography column that contains the activated silicagel ( $2 \%$ deactivated alumina) to remove the fatty acid residue and a layer of anhydrous sodium sulphate to absorb the water, if any, (50) $\mathrm{ml}$ of benzene to obtain the aromatic fraction that evaporates to the extent of dehydration and then dissolved in (5) $\mathrm{ml}$ of hexane for the purpose of measuring the total concentration of aromatic hydrocarbons.

The procedure used by (22) was employed to determine the fat content of molluscs samples. Three grams of each freeze- dried sample was soxhlet extracted with a 2:1 mixture of petroleum ether and acetone for 24-hours. The extracts were reduced in volume in a rotary vacuum evaporator, and subsequently reduced to exactly $1 \mathrm{ml}$. Ten $\mu$ l of the concentrated extracts were taken by a Hamilton syringe and weighted after evaporation of the solvent.

\section{Results and Discussion: \\ Environmental parameters}

The hydrological condition of the Shatt Al-Arab River basin is affected by several factors including conditions at the upper reaches of the Tigris and Euphrates rivers, the status of advancing flood tides from the Arabian Gulf, seepage of saline ground water into the basin, as well as the impact of climate conditions prevailing in the region on discharge rates and the payload of the river (23).

The basic statistical seasonal variations for the water quality parameters are summarized in Table 1 and illustrated in Figure 2,3,4 and 5. Temperature is a high-fluctuations environmental factor, which consider important parameter which regulated the biogeochemical processes in ecosystem (24).Temperature affects the solubility and, consequently, the availability of gases such as oxygen in water (25). it also affects the toxicity of some chemicals in water systems as well as the sensitivity of living organisms to toxic substances(26). In this study, the variability in temperature values at the study locations may have resulted from the weather condition at the time of study $\left(13^{\circ} \mathrm{C}\right.$ to $\left.39^{\circ} \mathrm{C}\right)$.

Shatt Al-Arab river has high values of dissolved oxygen due to continuous diffusion, mixing, and the role of phytoplankton, and occurrence of different aquatic plants, The dissolved oxygen is essential for aquatic life, as it is needed to keep organisms alive. The DO content of water is influenced by the sources, raw water temperature and chemical or biological processes taking place in the aquatic system (27). Our results showed that the DO concentrations range from $(6.5 \mathrm{mg} / 1$ to $3.84 \mathrm{mg} / \mathrm{l})$.

$\mathrm{pH}$ is an important factor to describing the chemical processes state in water, $\mathrm{PH}$ mean is a measure the concentration of hydrogen ion $(\mathrm{H}+)$ in water $(28)$ The $\mathrm{pH}$ results show seasonal differences but for all. Stations fall within the acceptable range of (8.15-7.17); the average values tend to be slightly alkaline during the study period which is consistent with previous studies made on aquatic ecosystems in Southern $\operatorname{Iraq}(27,29)$. The $\mathrm{pH}$ is an important parameter that determines the suitability of water for different purposes.

EC estimates the amount of total solids or amount of total dissolved ions in water. The EC of water generally increases as the levels of dissolved pollutants and salinity increases(30). In this study, EC showed clear seasonal differences $(4.75 \mathrm{~ms} / \mathrm{cm}-2.59 \mathrm{~ms} / \mathrm{cm})$.

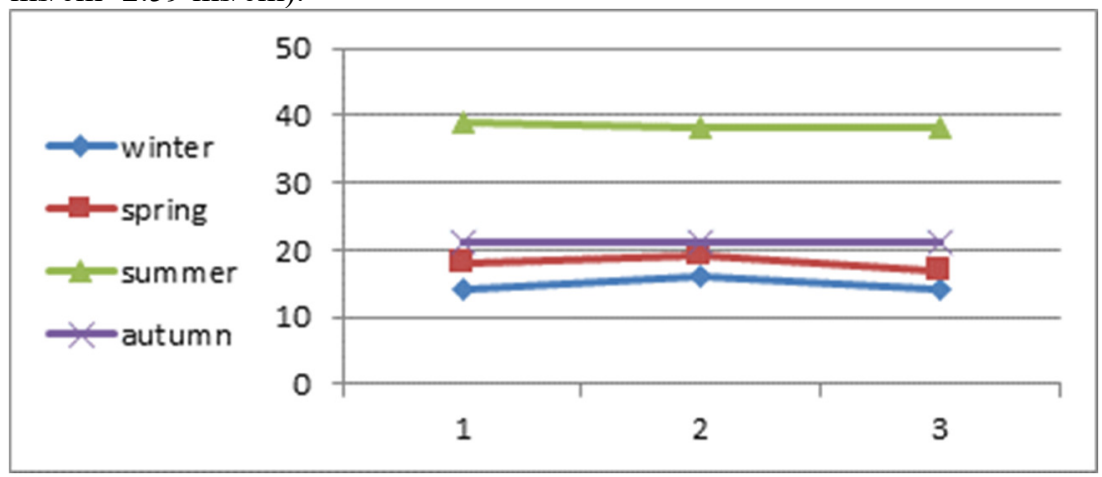

(Fig.2) Water temperatures $\left({ }^{\circ} \mathrm{C}\right)$ at the studied stations 


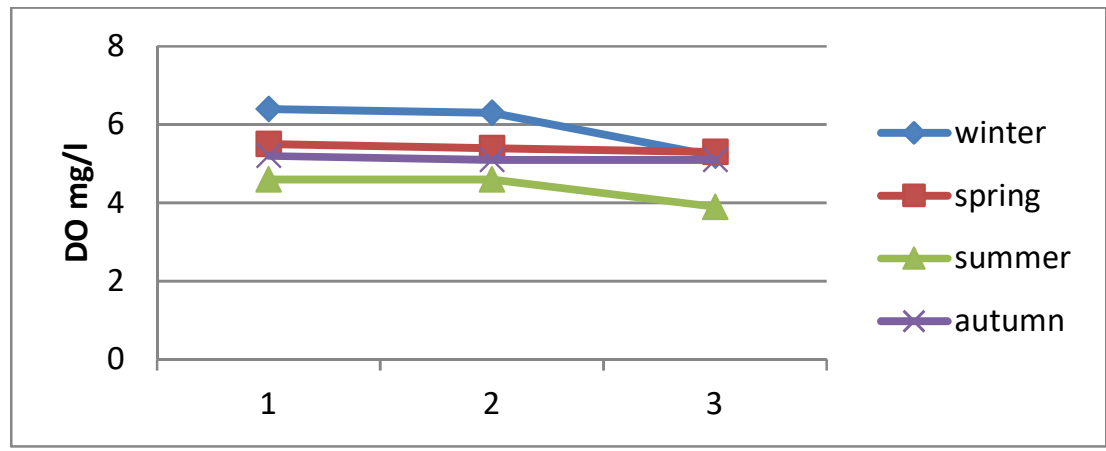

(Fig.3) Dissolved Oxygen (DO) concentrations (mg/l) at the studied stations

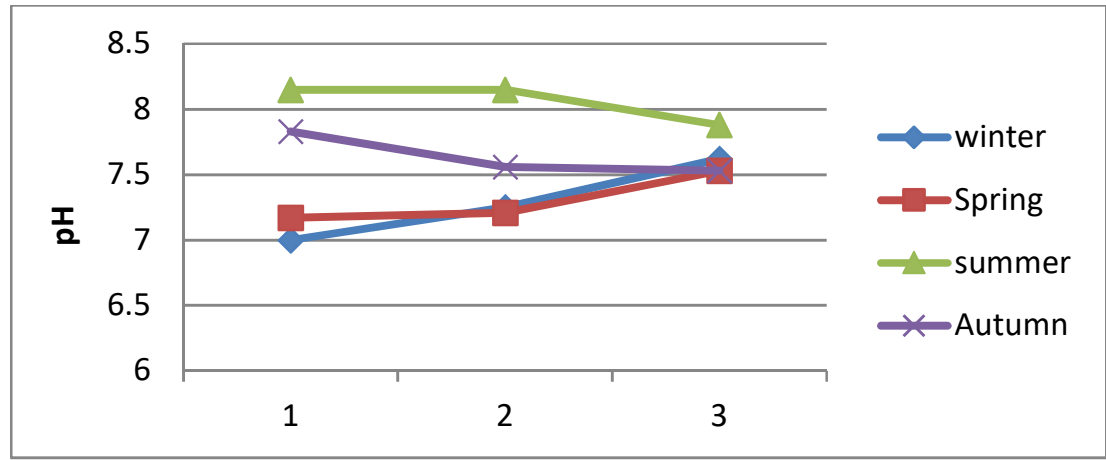

(Fig.4) Seasonal variation of $(\mathrm{pH})$ at the studied stations

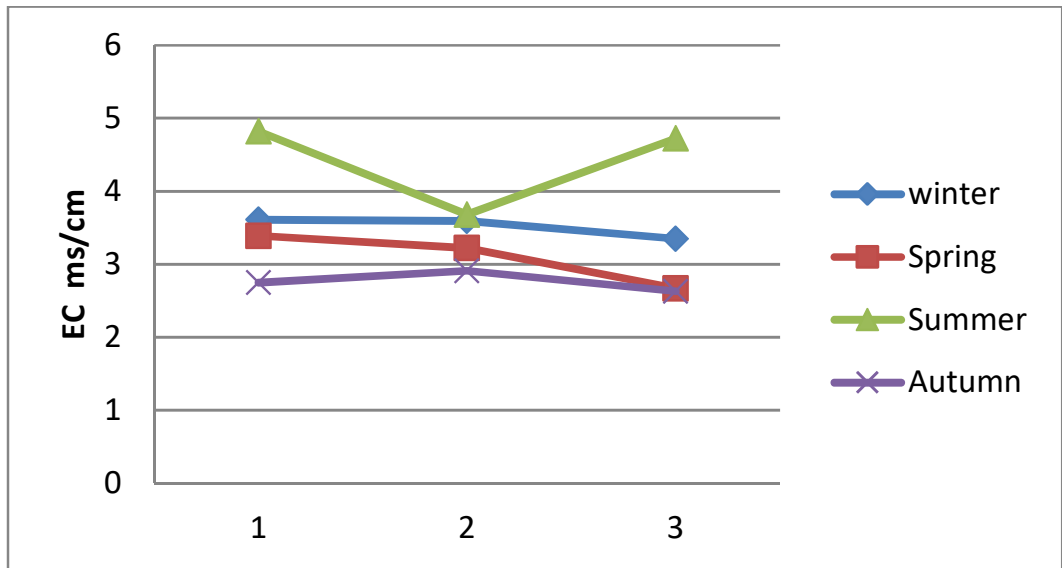

(Fig.5) Electrical Conductivity $(\mathrm{EC} \mathrm{ms} / \mathrm{cm})$ at the studied stations 
Table (1) Environmental measurements of the three stations during different seasons.

\begin{tabular}{|c|c|c|c|c|c|c|c|}
\hline & & $\begin{array}{c}\text { Station } \\
1\end{array}$ & & Station 2 & & Station 3 & Season \\
\hline Parameters & Range & Mean \pm SD & Range & Mean \pm SD & Range & $\begin{array}{c}\text { Mean } \pm \\
\text { SD }\end{array}$ & \\
\hline PH & $(7.15-7.16)$ & $7-0.005$ & $(7.21--7.32)$ & $7.25-0.06$ & $(7.55--7.71)$ & $7.62-0.08$ & \\
\hline EC & $(3.55-3.69)$ & $3.61-0.07$ & $(3.55-3.66)$ & $3.59-0.06$ & $(3.28-3.46)$ & $3.35-0.094$ & Winter \\
\hline DO & $(6.3-6.5)$ & $6.4-0.1$ & $(6.3-6.4)$ & $6.3-0.057$ & $(5.1-5.3)$ & $5.2-0.1$ & \\
\hline Water Temp. & $(14-15)$ & $14-0.57$ & $(15-16)$ & $16-0.57$ & $(13-15)$ & $14-1$ & \\
\hline PH & $(7.17-7.18)$ & $7.17-0.005$ & $(7.10--7.28)$ & $7.21-0.101$ & $(7.47--7.56)$ & $7.53-0.058$ & \\
\hline EC & $(3.32-3.44)$ & $3.39-0.062$ & $(3.21-3.24)$ & $3.22-0.015$ & $(2.61-2.73)$ & $2.67-0.061$ & Spring \\
\hline DO & $(5.4-5.6)$ & $5.5-0.1$ & $(5.4-5.5)$ & $5.4-0.057$ & $(5.2-5.4)$ & $5.3-0.1$ & \\
\hline Water Temp. & $(17-19)$ & $18-1$ & $(18-20)$ & $19-1$ & $(17-18)$ & $17-0.577$ & \\
\hline PH & $(8.14--8.16)$ & $8.15-0.01$ & $(8.15--8.16)$ & $8.15-0.005$ & $(7.89--7.98)$ & $7.88-0.095$ & \\
\hline EC & $(4.75-4.88)$ & $4.82-0.066$ & $(3.64-3.76)$ & $3.68-0.066$ & $(4.67-4.76)$ & $4.72-0.049$ & Summer \\
\hline DO & $(4.6-4.7)$ & $4.6-0.057$ & $(4.5-4.7)$ & $4.6-0.1$ & $(3.84-3.98)$ & $3.9-0.07$ & \\
\hline Water Temp. & $(38-39)$ & $39-0.577$ & $(38-39)$ & $38-0.577$ & $(37-38)$ & $38-0.577$ & \\
\hline PH & $(7.83--7.84)$ & $7.83-0.005$ & $(7.53--7.63)$ & $7.56-0.055$ & $(7.43--7.63)$ & $7.53-0.1$ & \\
\hline EC & $(2.69-2.85)$ & $2.75-0.085$ & $(2.89-2.93)$ & $2.91-0.020$ & $(2.59-2.69)$ & $2.63-0.051$ & \\
\hline DO & $(5.1-5.3)$ & $5.2-0.1$ & $(5.0-5.2)$ & $5.1-0.115$ & $(5.1-5.4)$ & $5.2-0.152$ & Autumn \\
\hline Water Temp. & $(21-22)$ & $21-0.577$ & $(20-22)$ & $21-1$ & $(21-22)$ & $21-0.577$ & \\
\hline
\end{tabular}

\section{PAH concentration}

PAHs do not usually exist as separate entities in environmental media; they are often regarded as a mixture and the total concentration of their mixture is often used to describe their distribution (31). 16 PAHs recommended by the (US EPA) were investigated, The results of the chromatographic gas system showed that concentrations ranged from (1.4754ng / 1) in the summer in the first station to $(3.4215 \mathrm{ng} / 1)$ in winter at the third station(table 2,3,4 and Fig.6). The results showed that the total concentrations of PAHs introduced into the environment are higher in winter than in summer This is confirmed by (22) and (32) explained that the increase in the total concentration of PAHs in autumn and winter is due to the fact that aromatic compounds entering the environment are higher in autumn and winter due to the increase in fuel and wood burning, which is used in heating during the winter. As well as the low rate of evaporation of PAHs in the winter and reduce the effectiveness of various microorganisms in the degradation of these compounds with low temperatures (33). While low concentrations in the spring and summer are due to the warm climate of Iraq in summer, where high temperatures cause PAHs to evaporate from water(34) .High temperatures also encourage microorganisms to break down these compounds, especially low molecular weights (35) The process of oxidation is due to the long period of solar brightness and also because of the intensity of solar radiation (33).

Generally, the high molecular weight (HMW) PAHs with $\geq 4$ rings was predominant in the rivers samples . This may be attributed to their low solubility in water, less volatility due to their molecular size and higher persistence in aqueous environment when compared to the low molecular weight (LMW) PAHs (36). The major source of HMW PAHs can be linked to anthropogenic activities( 37). HMW PAHs are more persistent than LMW PAHs in the environment due to their increased resistance to oxidation, reduction and vapourisation as molecular weight increases (38). LMW PAHs such as naphthalene and fluorene have more significant acute toxicity to aquatic organisms than HMW PAHs but are non-carcinogenic(31). Some HMW PAHs such as benzo[a]pyrene and benzo[b] fluoranthene are carcinogenic and mutagenic to a wide variety of organisms including fish, birds and mammals( 39). 
Vol.9, No.14, 2019

Table (2) the concentrations of PAHs (ng / 1) in water in the study area during the year for the first station.

\begin{tabular}{|l|r|r|r|r|}
\hline \multicolumn{1}{|c|}{ Compounds } & \multicolumn{1}{c|}{ Summer } & \multicolumn{1}{c|}{ Autumn } & \multicolumn{1}{l|}{ Winter } & \multicolumn{1}{c|}{ Spring } \\
\hline Naphtalene & & & & \\
\hline 2-methyl naphthalene & & & & \\
\hline 1-methyl naphthalene & & & 0.1975 & \\
\hline Acenaphthlene & & & & \\
\hline Acenaphthene & & & 0.0314 & 0.1975 \\
\hline Fluorene & & 0.0594 & 0.1503 & 0.0684 \\
\hline Phenanthrene & & 0.0727 & 0.0533 & 0.0654 \\
\hline Anthracene & & 0.5215 & 0.1917 & 0.0987 \\
\hline Fluoranthene & 0.0678 & 0.0721 & 0.0317 & 0.0957 \\
\hline Pyrene & 0.6892 & 0.0862 & 0.207 & 0.1342 \\
\hline Benzo[a]fluoranthene & 0.0964 & 0.018 & 0.0465 & 0.2451 \\
\hline Chrysene & 0.0502 & 0.4575 & 1.0383 & 0.0958 \\
\hline Benzo[b]fluoranthene+Benzo[k]Fluoranthene & 0.0392 & 0.0667 & 0.0998 & 0.3761 \\
\hline Di benz[a]pyrene & 0.0392 & 0.1609 & 1.0926 & 0.0618 \\
\hline Indeno[1,2,3-c,d]pyrene+Di benz[a,h]anthracene & 0.4934 & 0.4987 & 0.0733 & 0.5664 \\
\hline Benzo[g,h,i]perylene & & 0.0651 & 0.0644 & 0.0343 \\
\hline Total & 1.4754 & 2.0788 & 3.2778 & 2.0394 \\
\hline LPAHs & & 0.6536 & 0.6242 & 0.43 \\
\hline HPAHs & 1.4754 & 1.4252 & 2.6536 & 1.6094 \\
\hline L/H & & 0.458 & 0.235 & 0.267 \\
\hline Fl/Py & 0.098 & 0.836 & 0.153 & 0.713 \\
\hline Phenanthrene/ Anthracene & & 0.139 & 0.278 & 0.662 \\
\hline
\end{tabular}

Table (3) the concentrations of PAHs (ng / 1) in water in the study area during the year for the second station.

\begin{tabular}{|c|c|c|c|c|}
\hline Compound & Summr & Autumn & Winter & Spring \\
\hline Naphtalene & & & 0.0701 & \\
\hline \multicolumn{5}{|l|}{ 2-methyl naphthalene } \\
\hline 1-methyl naphthalene & & & 0.2475 & 0.6921 \\
\hline Acenaphthlene & 0.0148 & 0.0821 & & \\
\hline Acenaphthene & & & 0.0546 & 0.1526 \\
\hline Fluorene & 0.0961 & 0.0904 & 0.2034 & 0.0745 \\
\hline Phenanthrene & & 0.0287 & & 0.0952 \\
\hline Anthracene & & 0.4015 & 0.4973 & 0.0837 \\
\hline Fluoranthene & 0.0568 & & 0.0578 & \\
\hline Pyrene & 0.0992 & 0.0652 & 0.0772 & 0.3412 \\
\hline Benzo[a]fluoranthene & & 0.0108 & 0.0667 & 0.1914 \\
\hline Chrysene & 0.0232 & 0.5873 & & \\
\hline Benzo[b]fluoranthene+Benzo[k]Fluoranthene & 0.0692 & 0.0678 & 0.0908 & 0.2641 \\
\hline Di benz[a]pyrene & 0.0902 & 0.1409 & 1.4427 & 0.0908 \\
\hline Indeno[1,2,3-c,d]pyrene+Di benz[a,h]anthracene & 0.0845 & 0.4748 & 0.3033 & 0.6624 \\
\hline Benzo[g,h,i]perylene & 0.5681 & 0.0991 & 0.2542 & \\
\hline Total & 1.1131 & 2.0486 & 3.3656 & 2.648 \\
\hline LPAHs & 0.1109 & 0.6027 & 1.0729 & 1.0981 \\
\hline HPAHs & 0.9912 & 1.4459 & 2.2927 & 1.5499 \\
\hline $\mathbf{L} / \mathbf{H}$ & 0.111 & 0.416 & 0.467 & 0.708 \\
\hline $\mathbf{F l} / \mathbf{P y}$ & 0.572 & & 0.748 & \\
\hline Phenanthrene/ Anthracene & & 0.071 & & 1.137 \\
\hline
\end{tabular}


Table (4) the concentrations of PAHs (ng / 1) in water in the study area during the year for the third station.

\begin{tabular}{|l|r|r|r|r|}
\hline Compound & Summer & Autumn & Winter & Spring \\
\hline Naphtalene & & & & \\
\hline 2-methyl naphthalene & & & & \\
\hline 1-methyl naphthalene & & & 0.9752 & 0.9135 \\
\hline Acenaphthlene & & & & 0.0367 \\
\hline Acenaphthene & & & 0.1565 & \\
\hline Fluorene & 0.1591 & 0.0444 & & 0.0741 \\
\hline Phenanthrene & 0.0858 & & & \\
\hline Anthracene & & 0.4015 & 0.3431 & 0.0787 \\
\hline Fluoranthene & & 0.0347 & 0.0752 & 0.0925 \\
\hline Pyrene & 0.0382 & & 0.0782 & 0.2041 \\
\hline Benzo[a]fluoranthene & & 0.1589 & 0.1447 & 0.3044 \\
\hline Chrysene & 0.1092 & 0.4743 & 0.0931 & 0.0783 \\
\hline Benzo[b]fluoranthene+Benzo[k]Fluoranthene & & 0.2078 & & \\
\hline Di benz[a]pyrene & 0.2372 & 0.2589 & 1.0297 & 0.1983 \\
\hline Indeno[1,2,3-c,d]pyrene+Di benz[a,h]anthracene & 0.1992 & 0.3081 & 0.3356 & 0.7349 \\
\hline Benzo[g,h,i]perylene & 0.4989 & 0.1219 & 0.1902 & 0.0921 \\
\hline Total & 1.3276 & 2.0105 & 3.4215 & 2.8076 \\
\hline LPAHs & 0.2449 & 0.4459 & 1.4748 & 1.103 \\
\hline HPAHs & 1.0827 & 1.5646 & 1.9467 & 1.7046 \\
\hline L/H & 0.226 & 0.284 & 0.757 & 0.647 \\
\hline Fl/Py & & & 0.961 & 0.453 \\
\hline Phenanthrene/Anthracene & & & & \\
\hline
\end{tabular}
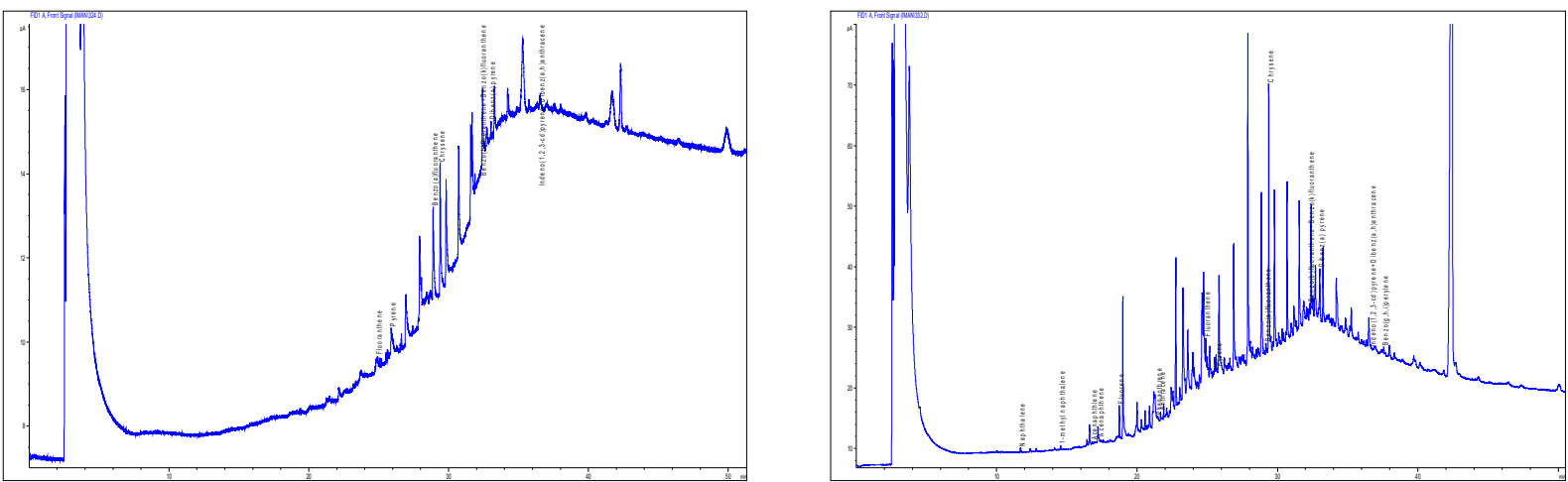

Summer season

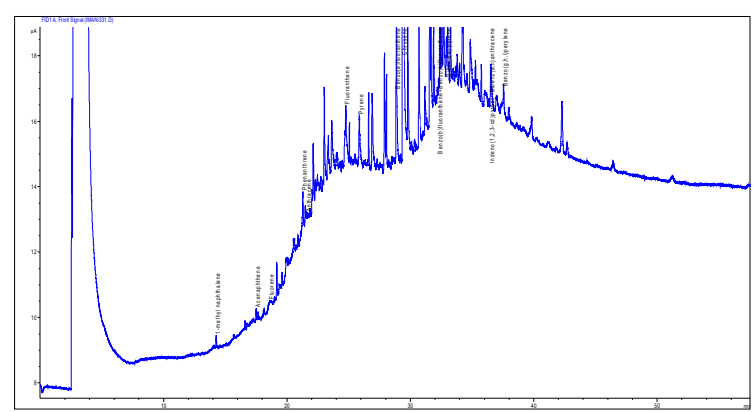

Winter season

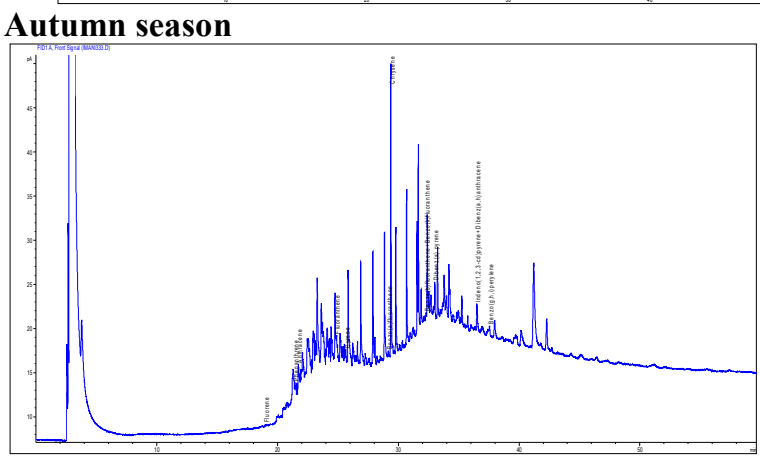

Spring season

(Fig.6) :Chromatograms of PAHs compounds in water samples of the studied stations during the season

While the concentration in molluscs varied from $3.672 \mathrm{ng} / \mathrm{g}$ at the third station in the summer to $7.257 \mathrm{ng} / \mathrm{g}$ at the first station in the winter in the M.nodosa and from $0.876 \mathrm{ng} / \mathrm{g}$ in the summer at the first station to $3.506 \mathrm{ng} / \mathrm{g}$ in the third station in the winter in the T.jordani and from $1.778 \mathrm{ng} / \mathrm{g}$ at the third station in the summer to 5.924ng / $g$ at the second station in the winter in the M.tuberculata and from $4.07 \mathrm{ng} / \mathrm{g}$ in the summer at the second station to $9.093 \mathrm{ng} / \mathrm{g}$ at the second station in the winter(table 6,7,8 and fig 7)

The current results showed that the concentrations of PAHs in the water column were lower than those in the 
molluscs. This may be the result of optical oxidation and the deposition of PAHs from the water column, making PAHs with low molecular weight predominant in surface water while the higher molecular weight compounds predominated in the molluscs

\section{Sources of PAHs}

The sources of PAHs can either be petrogenic i.e., released from petroleum products or pyrogenic due to the combustion of biomass. Diagnostic ratios have been designed and used to distinguish the sources of PAHs due to their stability, physical and chemical attributes (31). Table 2,3 and 4 shows the diagnostic ratios of the PAHs obtained in this study and their possible sources in the water. The ratio of LPAHs/HPAHs in Shatt Al-Arab river were $>1$ in all station and sesonal which implies that the source of the PAHs was from pyrogenic derived from incomplete combustion of fuel at all stations.

The ratio( fluoranthene/ Pyrene ) was less than one at the first station and for all seasons, Either in the second and third stations The(FI/Py) ratio was disadvantage because most water sample had undetectable fluoranthene value and the other samples had undetectable Pyrene values, only few sample had fluoranthene and Pyrene values together, because that the ratio ranged from 0.5 to 0.9 and indicate the source of PAHs was Petrogenic. Also, the(Phenanthrene/ Anthracene) ratio was disadvantage because most water sample had undetectable Phenanthrene value and the other samples had undetectable Anthracene values , only few sample had Phenanthrene and Anthracene values together, because that the ratio ranged from 0.139 to 1.13 and indicate the source of PAHs was pyrogenic. This study illustrates the defect of these two indicators in water samples because most samples have undetectable values.

Table 5,6 and 7 shows the diagnostic ratios of the PAHs obtained in this study and their possible sources in the molluscs. The ratio of LPAHs/HPAHs in M.nodosa were $>1$ in all station and seasonal which implies that the source of the PAHs was from pyrogenic derived from incomplete combustion of fuel at all stations. The ratio( fluoranthene/ Pyrene ) was more than one at all station and for all seasons, except in the third station in the winter was less than (1) The ratio of (Phenanthrene / Anthracene) is less than the number (10) in all station and seasons and this indicates that the origin of PAHs in snail samples M.nodosa is Petrogenic and Pyrogenic.

The ratio of LPAHs/HPAHs in T.jordani were $>1$ in all station and seasonal, except In the first station in the summer and autumn, the ratio was less than 1. This shows that the origin of PAHs is Petrogenic and a low amount of Pyrogenic. The ratio( fluoranthene/ Pyrene ) was more than one at all station and for all seasons, except in the first station in the winter and spring was less than (1) The ratio of (Phenanthrene / Anthracene) is less than the number (10) in all station and seasons and this indicates that the origin of PAHs in snail samples T.jordani is Petrogenic and Pyrogenic (table 8,9 and 10)

The ratio of LPAHs/HPAHs in M.tuberculata were $>1$ in all station and seasonal which implies that the source of the PAHs was from pyrogenic derived from incomplete combustion of fuel at all stations. The ratio( fluoranthene/ Pyrene ) was more than one at all station and for all seasons and The ratio of (Phenanthrene / Anthracene) is less than the number (10) in all station and seasons and this indicates that the origin of PAHs in snail samples M.tuberculata is Petrogenic and Pyrogenic( table 11,12and 13)

(Table 14,15 and16) shows The ratio of LPAHs/HPAHs in B.bengalensis were $>1$ in all station and seasonal ,except In the third station in the spring, the ratio was less than (1)This shows that the origin of PAHs is Petrogenic and a low amount of Pyrogenic. The ratio( fluoranthene/ Pyrene ) was more than one at all station and for all seasons g except In the first station in the summer This shows that the origin of PAHs is Petrogenic and a low amount of Pyrogenic. and The ratio of (Phenanthrene / Anthracene) is less than the number (10) in all station and seasons and this indicates that the origin of PAHs in snail samples B.bengalensis is Petrogenic and Pyrogenic 
Table (5) the concentrations of PAHs (ng / 1) in M.nodosa in the study area during the year for the first station.

\begin{tabular}{|c|c|c|c|c|}
\hline \multicolumn{5}{|c|}{ M.nodosa } \\
\hline Compound & summer & Autumn & Winter & Spring \\
\hline \multicolumn{5}{|l|}{ Naphtalene } \\
\hline 2-methyl naphthalene & & & $0.56 \overline{1}$ & $0.56 \overline{6}$ \\
\hline 1-methyl naphthalene & 0.378 & 0.421 & 1.399 & 0.542 \\
\hline Acenaphthylene & 0.361 & 0.541 & 0.703 & 0.499 \\
\hline Acenaphthene & 0.267 & 0.343 & 0.585 & 0.456 \\
\hline Fluorene & 0.199 & 0.445 & 0.489 & 0.411 \\
\hline Phenanthrene & 0.491 & 0.389 & 0.632 & 0.374 \\
\hline Anthracene & 0.376 & 0.363 & 0.591 & 0.266 \\
\hline Fluoranthene & 0.342 & 0.254 & 0.392 & 0.374 \\
\hline Pyrene & 0.232 & 0.209 & 0.265 & 0.246 \\
\hline Benzo[a]fluoranthene & 0.179 & 0.257 & 0.291 & 0.271 \\
\hline Chrysene & 0.249 & 0.187 & 0.238 & 0.208 \\
\hline Benzo[b]fluoranthene+Benzo[k]Fluoranthene & 0.267 & 0.261 & 0.256 & 0.177 \\
\hline Di benz[a]pyrene & 0.311 & 0.256 & 0.189 & 0.162 \\
\hline Indeno[1,2,3-c,d]pyrene+Di benz[a,h]anthracene & 0.166 & 0.141 & 0.098 & 0.121 \\
\hline Benzo[g,h,i]perylene & 0.104 & 0.129 & 0.094 & 0.153 \\
\hline Total & 3.922 & 4.196 & 6.783 & 4.826 \\
\hline LPAHs & 2.072 & 2.502 & 4.96 & 3.114 \\
\hline HPAHs & 1.85 & 1.694 & 1.823 & 1.712 \\
\hline $\mathbf{L} / \mathbf{H}$ & 1.12 & 1.476 & 2.72 & 1.818 \\
\hline $\mathbf{F l} / \mathbf{P y}$ & 1.474 & 1.215 & 1.479 & 1.520 \\
\hline Phenanthrene/ Anthracene & 1.305 & 1.071 & 1.069 & 1.406 \\
\hline
\end{tabular}

Table (6) the concentrations of PAHs (ng / 1) in M.nodosa in the study area during the year for the second station.

\begin{tabular}{|c|c|c|c|c|}
\hline \multicolumn{5}{|c|}{ M.nodosa } \\
\hline Compound & summer & Autumn & Winter & Spring \\
\hline \multicolumn{5}{|l|}{ Naphtalene } \\
\hline 2-methyl naphthalene & & 0.412 & 0.583 & \\
\hline 1-methyl naphthalene & 0.401 & 0.436 & 0.713 & 0.584 \\
\hline Acenaphthylene & 0.396 & 0.568 & 1.291 & 0.521 \\
\hline Acenaphthene & 0.372 & 0.367 & 0.554 & 0.467 \\
\hline Fluorene & 0.202 & 0.459 & 0.495 & 0.416 \\
\hline Phenanthrene & 0.521 & 0.419 & 0.663 & 0.464 \\
\hline Anthracene & 0.399 & 0.391 & 0.604 & 0.346 \\
\hline Fluoranthene & 0.362 & 0.321 & 0.665 & 0.461 \\
\hline Pyrene & 0.284 & 0.304 & 0.412 & 0.363 \\
\hline Benzo[a]fluoranthene & 0.239 & 0.277 & 0.331 & 0.271 \\
\hline Chrysene & 0.249 & 0.289 & 0.338 & 0.268 \\
\hline Benzo[b]fluoranthene+Benzo[k]Fluoranthene & 0.277 & 0.291 & 0.269 & 0.199 \\
\hline Di benz[a]pyrene & & & 0.211 & 0.261 \\
\hline Indeno[1,2,3-c,d]pyrene+Di benz[a,h]anthracene & 0.215 & & 0.128 & 0.222 \\
\hline \multicolumn{5}{|l|}{ Benzo[g,h,i]perylene } \\
\hline Total & 3.917 & 4.534 & 7.257 & 4.843 \\
\hline LPAHs & 2.291 & 3.052 & 4.903 & 2.798 \\
\hline HPAHs & 1.626 & 1.482 & 2.354 & 2.045 \\
\hline $\mathbf{L} / \mathbf{H}$ & 1.408 & 2.059 & 2.082 & 1.368 \\
\hline $\mathbf{F l} / \mathbf{P y}$ & 1.274 & 1.055 & 1.614 & 1.269 \\
\hline Phenanthrene/ Anthracene & 1.305 & 1.071 & 1.097 & 1.341 \\
\hline
\end{tabular}


Table (7) the concentrations of PAHs (ng / 1) in M.nodosa in the study area during the year for the third station.

\begin{tabular}{|c|c|c|c|c|}
\hline \multicolumn{5}{|c|}{ M.nodosa } \\
\hline Compound & summer & Autumn & Winter & Spring \\
\hline \multicolumn{5}{|l|}{ Naphtalene } \\
\hline \multicolumn{5}{|l|}{ 2-methyl naphthalene } \\
\hline 1-methyl naphthalene & 0.362 & 0.368 & 0.746 & \\
\hline Acenaphthylene & 0.349 & 0.582 & 1.547 & 0.545 \\
\hline Acenaphthene & 0.412 & 0.383 & 0.612 & 0.578 \\
\hline Fluorene & 0.213 & 0.391 & 0.521 & 0.455 \\
\hline Phenanthrene & 0.457 & 0.445 & 0.695 & 0.485 \\
\hline Anthracene & 0.432 & 0.296 & 0.638 & 0.331 \\
\hline Fluoranthene & 0.377 & 0.365 & 0.456 & 0.442 \\
\hline Pyrene & 0.344 & 0.338 & 0.472 & 0.384 \\
\hline Benzo[a]fluoranthene & 0.139 & 0.147 & 0.358 & 0.294 \\
\hline Chrysene & 0.143 & 0.249 & 0.369 & 0.283 \\
\hline Benzo[b]fluoranthene+Benzo[k]Fluoranthene & & 0.343 & 0.287 & 0.209 \\
\hline Di benz[a]pyrene & 0.197 & & 0.268 & 0.396 \\
\hline Indeno $[1,2,3-c, d]$ pyrene+Di benz[a,h]anthracene & 0.247 & & 0.164 & 0.267 \\
\hline \multicolumn{5}{|l|}{ Benzo[g,h,i]perylene } \\
\hline Total & 3.672 & 3.907 & 7.133 & 4.669 \\
\hline LPAHs & 2.225 & 2.465 & 4.759 & 2.394 \\
\hline HPAHs & 1.447 & 1.442 & 2.374 & 2.275 \\
\hline $\mathbf{L} / \mathbf{H}$ & 1.537 & 1.709 & 2.004 & 1.052 \\
\hline $\mathbf{F l} / \mathbf{P y}$ & 1.095 & 1.079 & 0.966 & 1.151 \\
\hline Phenanthrene/ Anthracene & 1.057 & 1.503 & 1.089 & 1.465 \\
\hline
\end{tabular}

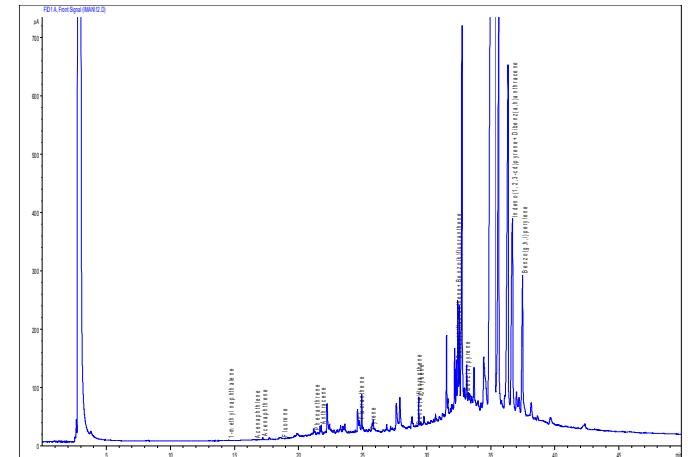

Summer season

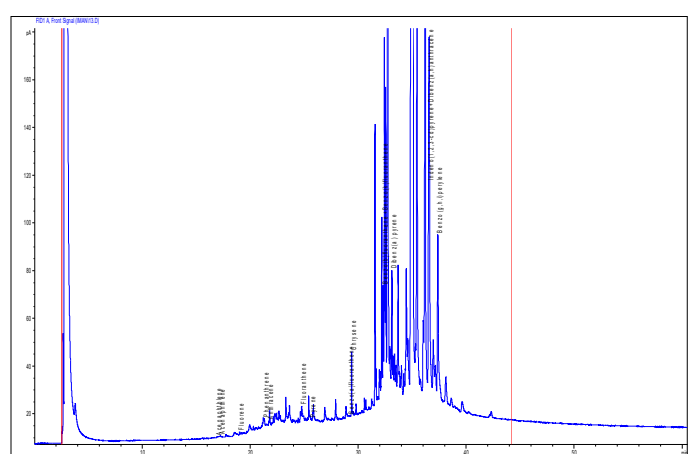

Winter season
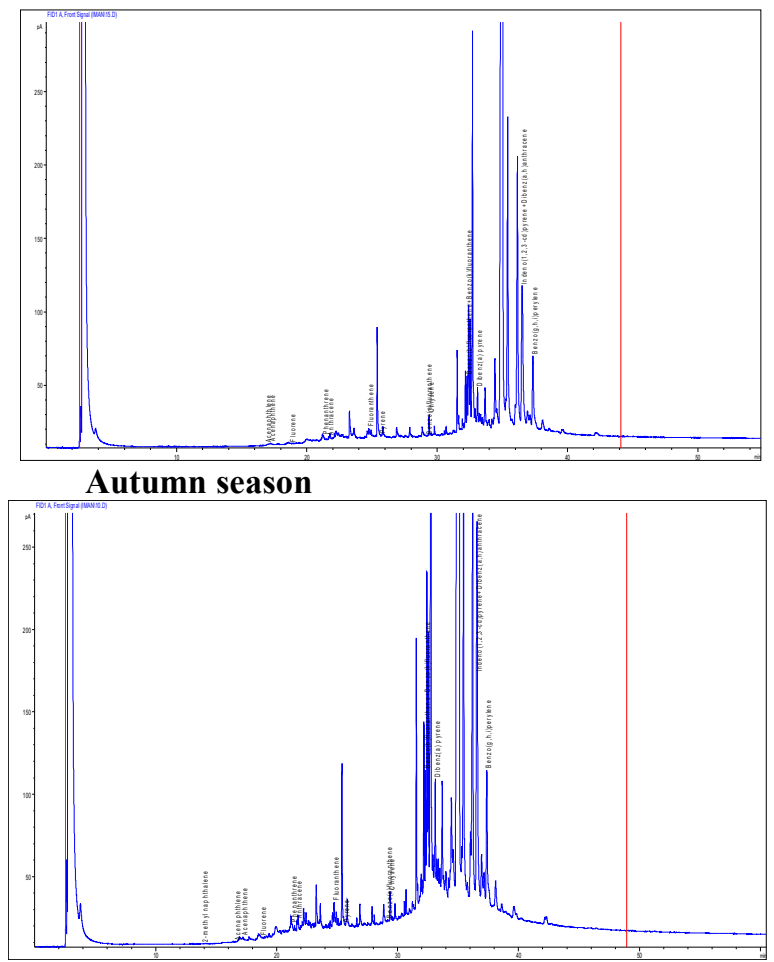

Spring season

(Fig.7) :Chromatograms of PAHs compounds in M.nodoas samples of the studied stations during the season 
Table (8) the concentrations of PAHs (ng / l) in T.jordani in the study area during the year for the first station.

\begin{tabular}{|c|c|c|c|c|}
\hline \multicolumn{5}{|c|}{ T.jordani } \\
\hline Compound & summer & Autumn & Winter & Spring \\
\hline \multicolumn{5}{|l|}{ Naphtalene } \\
\hline \multicolumn{5}{|l|}{ 2-methyl naphthalene } \\
\hline \multicolumn{5}{|l|}{ 1-methyl naphthalene } \\
\hline Acenaphthlene & 0.093 & & 0.265 & 0.127 \\
\hline Acenaphthene & 0.099 & 0.148 & 0.243 & \\
\hline Fluorene & 0.076 & 0.152 & 0.232 & 0.136 \\
\hline Phenanthrene & 0.075 & 0.166 & 0.205 & 0.102 \\
\hline Anthracene & 0.063 & 0.157 & 0.179 & 0.115 \\
\hline Fluoranthene & 0.068 & 0.119 & 0.141 & 0.034 \\
\hline Pyrene & 0.058 & 0.112 & 0.137 & 0.061 \\
\hline Benzo[a]fluoranthene & 0.059 & 0.105 & 0.176 & 0.069 \\
\hline Chrysene & 0.043 & 0.081 & 0.129 & 0.078 \\
\hline Benzo[b]fluoranthene+Benzo[k]Fluoranthene & 0.089 & 0.079 & 0.121 & 0.053 \\
\hline Di benz[a]pyrene & 0.056 & 0.066 & 0.179 & 0.071 \\
\hline Indeno $[1,2,3-c, d] p y r e n e+D i$ benz $[\mathrm{a}, \mathrm{h}]$ anthracene & 0.045 & 0.054 & 0.081 & 0.052 \\
\hline Benzo[g,h,i]perylene & 0.052 & 0.061 & 0.061 & 0.068 \\
\hline Total & 0.876 & 1.3 & 2.149 & 0.966 \\
\hline LPAHs & 0.406 & 0.623 & 1.124 & 0.48 \\
\hline HPAHs & 0.47 & 0.677 & 1.025 & 0.486 \\
\hline $\mathbf{L} / \mathbf{H}$ & 0.863 & 0.920 & 1.096 & 0.987 \\
\hline Fl/Py & 1.172 & 1.062 & 1.029 & 0.55 \\
\hline Phenanthrene/ Anthracene & 1.19 & 1.057 & 1.145 & 0.886 \\
\hline
\end{tabular}

Table (9) the concentrations of PAHs (ng / 1) in T.jordani in the study area during the year for the second station.

\begin{tabular}{|c|c|c|c|c|}
\hline \multicolumn{5}{|c|}{ T.jordani } \\
\hline Compound & summer & Autumn & Winter & Spring \\
\hline \multicolumn{5}{|l|}{ Naphtalene } \\
\hline 2-methyl naphthalene & & & & 0.313 \\
\hline 1-methyl naphthalene & 0.179 & 0.146 & & \\
\hline Acenaphthylene & 0.153 & 0.168 & 0.304 & 0.333 \\
\hline Acenaphthene & 0.139 & 0.181 & 0.356 & 0.229 \\
\hline Fluorene & 0.086 & 0.162 & 0.361 & 0.232 \\
\hline Phenanthrene & 0.095 & 0.106 & 0.317 & 0.209 \\
\hline Anthracene & 0.082 & 0.097 & 0.292 & 0.155 \\
\hline Fluoranthene & 0.074 & 0.094 & 0.253 & 0.135 \\
\hline Pyrene & 0.058 & 0.072 & 0.247 & 0.109 \\
\hline Benzo[a]fluoranthene & 0.079 & 0.085 & 0.256 & 0.141 \\
\hline Chrysene & 0.033 & 0.121 & 0.213 & 0.127 \\
\hline Benzo[b]fluoranthene+Benzo[k]Fluoranthene & & 0.119 & 0.235 & \\
\hline Di benz[a]pyrene & 0.067 & 0.106 & 0.262 & \\
\hline Indeno[1,2,3-c,d]pyrene+Di benz[a,h]anthracene & 0.052 & 0.094 & & 0.142 \\
\hline Benzo[g,h,i]perylene & 0.048 & 0.101 & & \\
\hline Total & 1.145 & 1.652 & 3.096 & 2.125 \\
\hline LPAHs & 0.734 & 0.86 & 1.63 & 1.471 \\
\hline HPAHs & 0.411 & 0.792 & 1.466 & 0.654 \\
\hline $\mathbf{L} / \mathbf{H}$ & 1.785 & 1.08 & 1.111 & 2.249 \\
\hline Fl/Py & 1.275 & 1.305 & 1.024 & 1.238 \\
\hline Phenanthrene/ Anthracene & 1.158 & 1.092 & 1.085 & 1.348 \\
\hline
\end{tabular}


Table (10) the concentrations of PAHs (ng / 1) in T.jordani in the study area during the year for the third station.

\begin{tabular}{|l|r|r|r|r|}
\hline \multicolumn{1}{|c|}{ T.jordani } & \multicolumn{1}{l|}{ summer } & Autumn & Winter & Spring \\
\hline Compound & & & & \\
\hline Naphtalene & & & & \\
\hline 2-methyl naphthalene & 0.135 & & & \\
\hline 1-methyl naphthalene & 0.176 & 0.123 & 0.454 & 0.374 \\
\hline Acenaphthylene & 0.158 & 0.168 & 0.467 & 0.437 \\
\hline Acenaphthene & 0.096 & 0.145 & 0.487 & 0.216 \\
\hline Fluorene & 0.099 & 0.117 & 0.374 & 0.237 \\
\hline Phenanthrene & 0.079 & 0.085 & 0.243 & 0.132 \\
\hline Anthracene & 0.074 & 0.078 & 0.238 & 0.235 \\
\hline Fluoranthene & 0.061 & 0.055 & 0.271 & 0.158 \\
\hline Pyrene & 0.104 & 0.075 & 0.262 & 0.102 \\
\hline Benzo[a]fluoranthene & 0.073 & 0.066 & 0.293 & 0.097 \\
\hline Chrysene & & 0.093 & 0.205 & \\
\hline Benzo[b]fluoranthene+Benzo[k]Fluoranthene & 0.121 & 0.111 & 0.212 & \\
\hline Di benz[a]pyrene & 0.093 & 0.059 & & 0.089 \\
\hline Indeno[1,2,3-c,d]pyrene+Di benz[a,h]anthracene & 0.048 & 0.091 & & \\
\hline Benzo[g,h,i]perylene & 1.317 & 1.266 & 3.506 & 2.077 \\
\hline Total & 0.743 & 0.638 & 2.025 & 1.396 \\
\hline LPAHs & 0.574 & 0.628 & 1.481 & 0.681 \\
\hline HPAHs & 1.294 & 1.015 & 1.367 & 2.049 \\
\hline L/H & 1.213 & 1.418 & 0.878 & 1.487 \\
\hline Fl/Py & 1.253 & 1.376 & 1.539 & 1.795 \\
\hline Phenanthrene/ Anthracene & & & \\
\hline
\end{tabular}
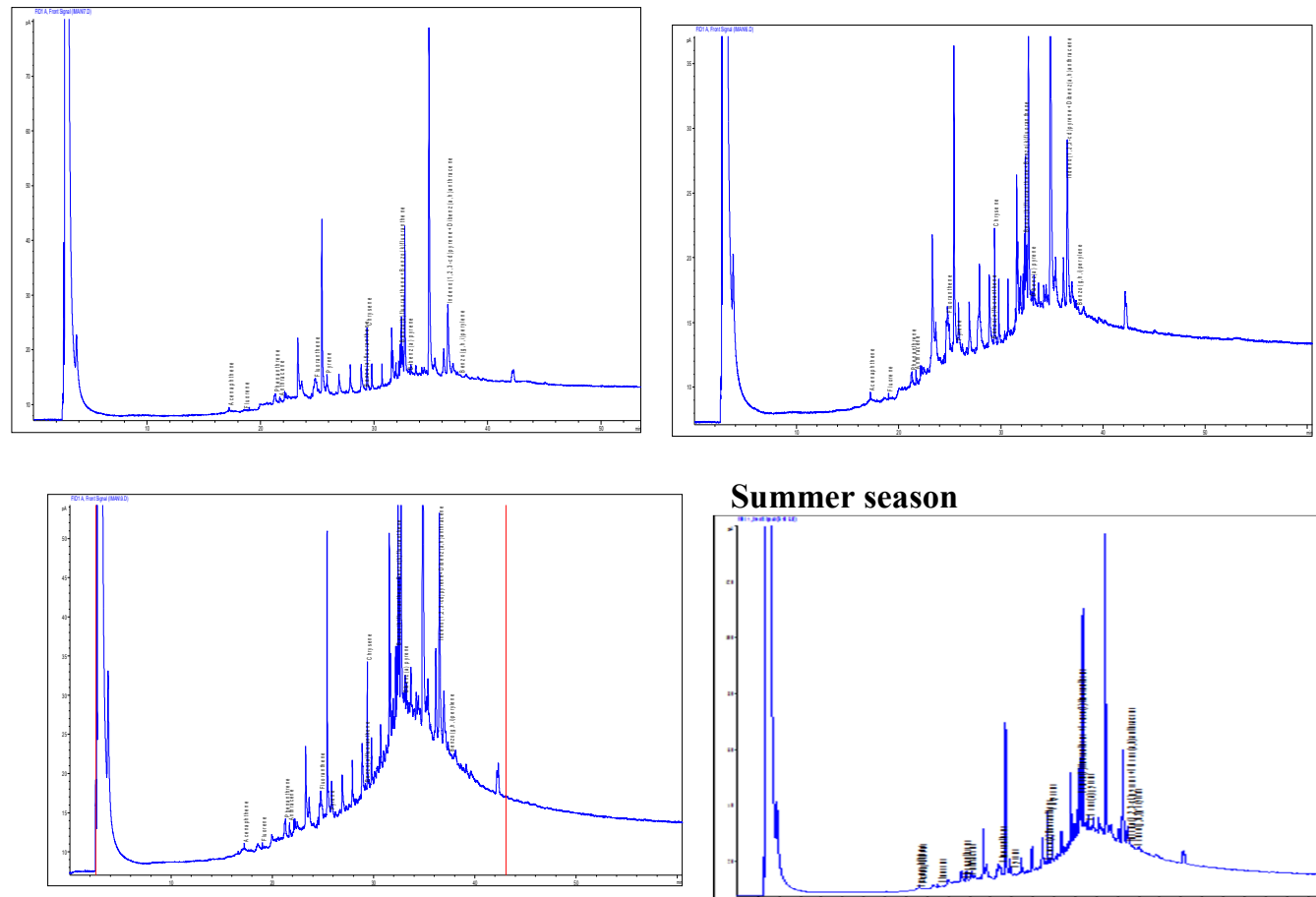

Summer season

Autumn season

Winter season
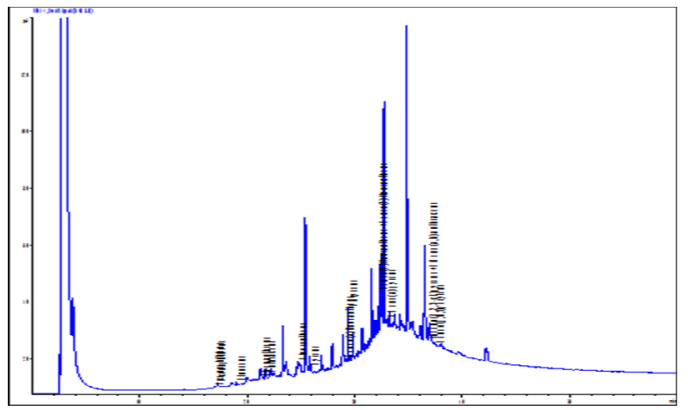

Spring season

(Fig.8) :Chromatograms of PAHs compounds in T.jordani samples of the studied stations during the season 
Vol.9, No.14, 2019

Table (11) the concentrations of PAHs (ng / 1) in M.tuberculata in the study area during the year for the first station.

\begin{tabular}{|c|c|c|c|c|}
\hline \multicolumn{5}{|c|}{ M.tuberculata } \\
\hline Compound & summer & Autumn & Winter & Spring \\
\hline \multicolumn{5}{|l|}{ Naphtalene } \\
\hline 2-methyl naphthalene & & & 0.391 & \\
\hline 1-methyl naphthalene & & & 0.332 & \\
\hline Acenaphthlene & & 0.252 & 1.121 & \\
\hline Acenaphthene & 0.169 & & 0.266 & \\
\hline Fluorene & 0.188 & 0.401 & 0.283 & 0.426 \\
\hline Phenanthrene & 0.238 & 0.411 & 0.274 & 0.346 \\
\hline Anthracene & 0.166 & 0.211 & 0.221 & 0.261 \\
\hline Fluoranthene & 0.098 & 0.189 & 1.216 & 0.159 \\
\hline Pyrene & 0.061 & 0.176 & 0.204 & 0.106 \\
\hline Benzo[a]fluoranthene & 0.103 & 0.109 & 0.199 & 0.173 \\
\hline Chrysene & 0.111 & & & 0.146 \\
\hline Benzo[b]fluoranthene+Benzo[k]Fluoranthene & 0.093 & 0.112 & 0.141 & 0.134 \\
\hline Di benz[a]pyrene & 0.115 & 0.017 & 0.152 & 0.115 \\
\hline Indeno[1,2,3-c,d]pyrene+Di benz[a,h]anthracene & 0.098 & 0.075 & 0.128 & 0.099 \\
\hline Benzo[g,h,i]perylene & 0.072 & 0.097 & 0.121 & 0.065 \\
\hline Total & 1.512 & 2.05 & 5.049 & 2.03 \\
\hline LPAHs & 0.761 & 1.275 & 2.888 & 1.033 \\
\hline HPAHs & 0.751 & 0.775 & 2.161 & 0.997 \\
\hline $\mathbf{L} / \mathbf{H}$ & 1.013 & 1.645 & 1.336 & 1.036 \\
\hline $\mathbf{F l} / \mathbf{P y}$ & 1.606 & 1.073 & 5.96 & 1.5 \\
\hline Phenanthrene/ Anthracene & 1.433 & 1.947 & 1.239 & 1.325 \\
\hline
\end{tabular}

Table (12) the concentrations of PAHs (ng / 1) in M.tuberculata in the study area during the year for the second station.

\begin{tabular}{|l|c|c|c|c|}
\hline \multicolumn{4}{|c|}{ M.tuberculata } & \multicolumn{1}{l|}{ Spring } \\
\hline Compound & summer & Autumn & & \\
\hline Naphtalene & & & & \\
\hline 2-methyl naphthalene & & 0.295 & 0.306 & \\
\hline 1-methyl naphthalene & 0.169 & 0.283 & 0.319 & 0.153 \\
\hline Acenaphthlene & 0.117 & 0.229 & 0.223 & 0.259 \\
\hline Acenaphthene & 0.177 & 0.162 & 0.326 & 0.379 \\
\hline Fluorene & 0.154 & 0.352 & 2.009 & 0.461 \\
\hline Phenanthrene & 0.162 & 0.341 & 0.348 & 0.331 \\
\hline Anthracene & & 0.234 & 0.251 & 0.238 \\
\hline Fluoranthene & 0.124 & 0.177 & 0.461 & 0.248 \\
\hline Pyrene & 0.118 & 0.164 & 0.224 & 0.246 \\
\hline Benzo[a]fluoranthene & 0.134 & & 1.003 & 0.265 \\
\hline Chrysene & 0.103 & 0.193 & 0.207 & 0.363 \\
\hline Benzo[b]fluoranthene+Benzo[k]Fluoranthene & & 0.097 & 0.12 & 0.141 \\
\hline Di benz[a]pyrene & 0.131 & 0.053 & 0.127 & \\
\hline Indeno[1,2,3-c,d]pyrene+Di benz[a,h]anthracene & & & & 0.096 \\
\hline Benzo[g,h,i]perylene & & & & 0.078 \\
\hline Total & 1.389 & 2.58 & 5.924 & 3.258 \\
\hline LPAHs & 0.779 & 1.896 & 3.782 & 1.821 \\
\hline HPAHs & 0.61 & 0.684 & 2.142 & 1.437 \\
\hline L/H & 1.277 & 2.771 & 1.765 & 1.267 \\
\hline Fl/Py & 1.05 & 1.079 & 2.058 & 1.008 \\
\hline Phenanthrene/ Anthracene & - & 1.457 & 1.386 & 1.39 \\
\hline
\end{tabular}


Table (13) the concentrations of PAHs (ng / 1) in M.tuberculata in the study area during the year for the third station.

\begin{tabular}{|c|c|c|c|c|}
\hline \multicolumn{5}{|c|}{ M.tuberculata } \\
\hline Compound & summer & Autumn & Winter & Spring \\
\hline \multicolumn{5}{|l|}{ Naphtalene } \\
\hline 2-methyl naphthalene & 0.124 & & 0.216 & \\
\hline 1-methyl naphthalene & 0.136 & 0.134 & 0.199 & 0.239 \\
\hline Acenaphthlene & 0.107 & 0.391 & 0.183 & 0.206 \\
\hline Acenaphthene & & 0.268 & & 0.392 \\
\hline Fluorene & 0.232 & 0.304 & 0.159 & 0.373 \\
\hline Phenanthrene & 0.198 & & 0.456 & 0.394 \\
\hline Anthracene & 0.157 & 0.255 & 0.315 & 0.181 \\
\hline Fluoranthene & 0.124 & 0.193 & 0.497 & 0.283 \\
\hline Pyrene & & 0.134 & 0.294 & 0.216 \\
\hline Benzo[a]fluoranthene & 0.339 & & 1.803 & 0.259 \\
\hline Chrysene & 0.156 & 0.12 & 0.672 & 0.336 \\
\hline Benzo[b]fluoranthene+Benzo[k]Fluoranthene & 0.094 & 0.102 & 0.116 & \\
\hline Di benz[a]pyrene & & 0.093 & 0.071 & 0.135 \\
\hline Indeno $[1,2,3-c, d]$ pyrene+Di benz $[a, h]$ anthracene & 0.111 & 0.095 & 0.068 & 0.106 \\
\hline \multicolumn{5}{|l|}{ Benzo[g,h,i]perylene } \\
\hline Total & $1 . \overline{778}$ & 2.089 & 5.049 & 3.12 \\
\hline LPAHs & 0.954 & 1.352 & 2.362 & 1.785 \\
\hline HPAHs & 0.824 & 0.737 & 2.321 & 1.335 \\
\hline $\mathbf{L} / \mathbf{H}$ & 1.157 & 1.834 & 1.017 & 1.337 \\
\hline $\mathbf{F l} / \mathbf{P y}$ & & 1.44 & 1.69 & 1.31 \\
\hline Phenanthrene/ Anthracene & $1 . \overline{2} 61$ & & 1.447 & 2.176 \\
\hline
\end{tabular}
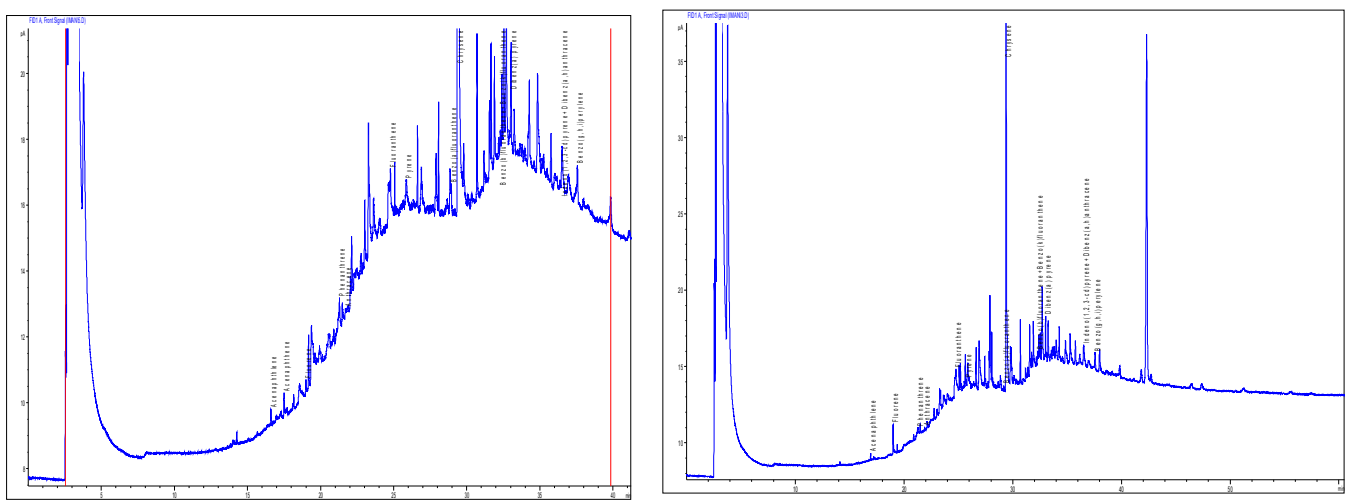

Summer season

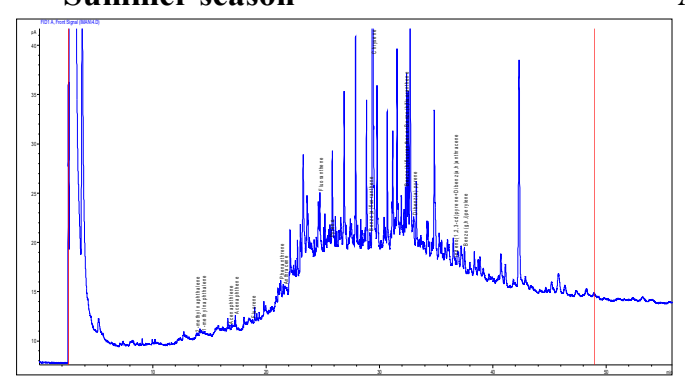

Winter season
Autumn season

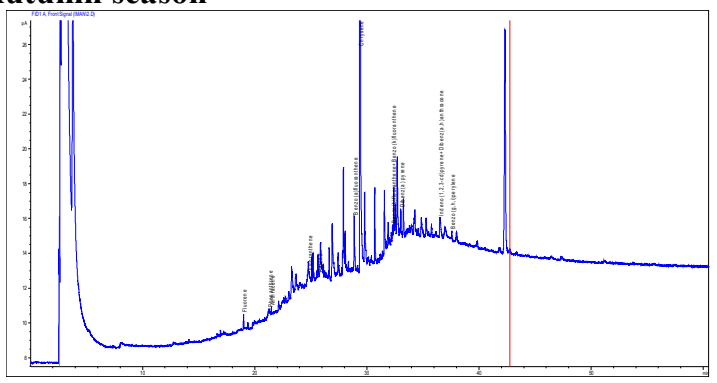

Spring season

(Fig.9) :Chromatograms of PAHs compounds in M.tuberculata samples of the studied stations during the season 
Table (14) the concentrations of PAHs (ng / 1) in B.bengalensis in the study area during the year for the first station.

\begin{tabular}{|l|r|r|r|r|}
\hline \multicolumn{3}{|c|}{ B.bengalensis } \\
\hline Compound & Summer & Autumn & Winter & Spring \\
\hline Naphtalene & & 0.365 & 0.599 & \\
\hline 2-methyl naphthalene & 0.342 & 0.297 & 0.365 & 0.394 \\
\hline 1-methyl naphthalene & 0.251 & 0.263 & 0.518 & 0.484 \\
\hline Acenaphthylene & 0.427 & 0.586 & 0.743 & 0.476 \\
\hline Acenaphthene & 0.412 & 0.595 & 0.675 & 0.602 \\
\hline Fluorene & 0.274 & 0.412 & 0.697 & 0.467 \\
\hline Phenanthrene & 0.487 & 0.512 & 0.523 & 0.613 \\
\hline Anthracene & 0.327 & 0.414 & 0.821 & 0.569 \\
\hline Fluoranthene & 0.421 & 1.034 & 0.698 & 0.538 \\
\hline Pyrene & 0.561 & 0.131 & 0.692 & 0.509 \\
\hline Benzo[a]fluoranthene & 0.297 & 0.112 & 0.732 & 0.633 \\
\hline Chrysene & 0.214 & 0.135 & 0.675 & 0.467 \\
\hline Benzo[b]fluoranthene+Benzo[k]Fluoranthene & 0.192 & 0.066 & 0.723 & 0.321 \\
\hline Di benz[a]pyrene & 0.106 & 0.055 & 0.349 & 0.231 \\
\hline Indeno[1,2,3-c,d]pyrene+Di benz[a,h]anthracene & 0.117 & 0.247 & 0.199 & 0.247 \\
\hline Benzo[g,h,i]perylene & 0.056 & 0.163 & 0.084 & 0.163 \\
\hline Total & 4.484 & 5.387 & 9.093 & 6.714 \\
\hline LPAHs & 2.52 & 3.444 & 4.941 & 3.605 \\
\hline HPAHs & 1.964 & 1.943 & 4.152 & 3.109 \\
\hline L/H & 1.283 & 1.772 & 1.190 & 1.159 \\
\hline Fl/Py & 0.750 & 7.893 & 1.008 & 1.056 \\
\hline Phenanthrene/ Anthracene & 1.489 & 1.236 & 0.637 & 1.077 \\
\hline
\end{tabular}

Table (15) the concentrations of PAHs (ng / 1) in B.bengalensis in the study area during the year for the second station.

\begin{tabular}{|l|r|r|r|r|}
\hline \multicolumn{3}{|c|}{ B.bengalensis } & \multicolumn{1}{l|}{ Sinter } & Spring \\
\hline Compound & summer & Autumn & & \\
\hline Naphtalene & & & & 0.461 \\
\hline 2-methyl naphthalene & 0.452 & 0.272 & 0.615 & 0.378 \\
\hline 1-methyl naphthalene & 0.366 & 0.256 & 0.583 & 0.506 \\
\hline Acenaphthylene & 0.387 & 0.562 & 0.943 & 0.629 \\
\hline Acenaphthene & 0.192 & & 0.495 & \\
\hline Fluorene & & 0.327 & 1.097 & \\
\hline Phenanthrene & 0.517 & 1.026 & 0.872 & \\
\hline Anthracene & 0.277 & 0.514 & 0.518 & \\
\hline Fluoranthene & 0.798 & 0.734 & 0.958 & 0.537 \\
\hline Pyrene & 0.214 & 0.347 & 0.784 & 0.492 \\
\hline Benzo[a]fluoranthene & 0.317 & 0.402 & & 0.536 \\
\hline Chrysene & 0.243 & 0.325 & 0.562 & 0.237 \\
\hline Benzo[b]fluoranthene+Benzo[k]Fluoranthene & & & 0.831 & 0.611 \\
\hline Di benz[a]pyrene & 0.076 & 0.035 & 0.449 & 0.257 \\
\hline Indeno[1,2,3-c,d]pyrene+Di benz[a,h]anthracene & 0.175 & 0.147 & 0.209 & 0.221 \\
\hline Benzo[g,h,i]perylene & 0.056 & 0.133 & 0.094 & 0.132 \\
\hline Total & 4.07 & 5.08 & 9.01 & 6.066 \\
\hline LPAHs & 2.191 & 2.957 & 5.123 & 3.043 \\
\hline HPAHs & 1.879 & 2.123 & 3.887 & 3.023 \\
\hline L/H & 1.166 & 1.392 & 1.317 & 1.006 \\
\hline Fl/Py & 3.728 & 2.115 & 1.221 & 1.091 \\
\hline Phenanthrene/ Anthracene & 1.866 & 1.996 & 1.683 & - \\
\hline
\end{tabular}


Table (16) the concentrations of PAHs (ng/1) in B.bengalensis in the study area during the year for the third station.

\begin{tabular}{|c|c|c|c|c|}
\hline \multicolumn{5}{|c|}{ B.bengalensis } \\
\hline Compound & summer & Autumn & Winter & Spring \\
\hline \multicolumn{5}{|l|}{ Naphtalene } \\
\hline 2-methyl naphthalene & & 1.426 & & \\
\hline 1-methyl naphthalene & 0.356 & 0.567 & 1.637 & 0.738 \\
\hline Acenaphthylene & 0.476 & 0.692 & 0.683 & 0.566 \\
\hline Acenaphthene & 1.042 & & 0.686 & 0.493 \\
\hline Fluorene & & 0.274 & 0.497 & 0.265 \\
\hline Phenanthrene & 0.678 & 0.669 & 0.888 & \\
\hline Anthracene & 0.307 & 0.544 & 0.872 & 0.969 \\
\hline Fluoranthene & 0.378 & 0.373 & 0.689 & 0.471 \\
\hline Pyrene & 0.341 & 0.271 & 0.834 & 0.328 \\
\hline Benzo[a]fluoranthene & 0.379 & 0.392 & & 0.631 \\
\hline Chrysene & 0.272 & 0.325 & 0.762 & 0.467 \\
\hline Benzo[b]fluoranthene+Benzo[k]Fluoranthene & 0.085 & 0.124 & 0.417 & 0.311 \\
\hline Di benz[a]pyrene & 0.091 & 0.126 & 0.496 & 0.275 \\
\hline $\begin{array}{l}\text { Indeno[1,2,3-c,d]pyrene+Di } \\
\text { benz[a,h]anthracene }\end{array}$ & 0.253 & 0.152 & 0.273 & 0.313 \\
\hline Benzo[g,h,i]perylene & 0.076 & 0.059 & 0.104 & 0.423 \\
\hline Total & 4.734 & 5.994 & 8.838 & 6.25 \\
\hline LPAHs & 2.859 & 4.172 & 5.263 & 3.031 \\
\hline HPAHs & 1.875 & 1.822 & 3.575 & 3.219 \\
\hline $\mathbf{L} / \mathbf{H}$ & 1.524 & 2.289 & 1.472 & 0.941 \\
\hline $\mathbf{F l} / \mathbf{P y}$ & 1.108 & 1.376 & 0.826 & 1.435 \\
\hline Phenanthrene/ Anthracene & 2.208 & 1.229 & 1.018 & \\
\hline
\end{tabular}
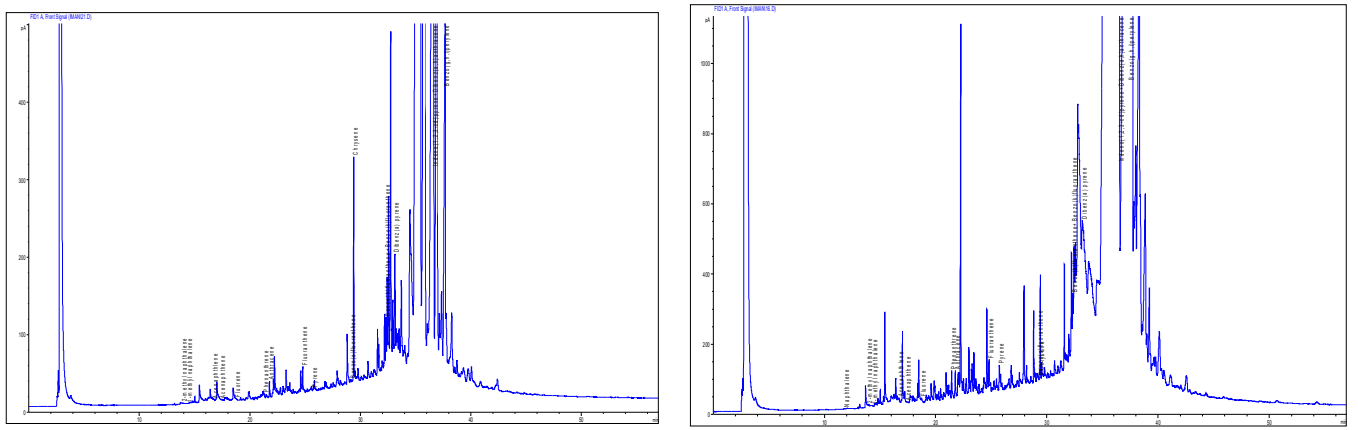

\section{Summer season}

Autumn season
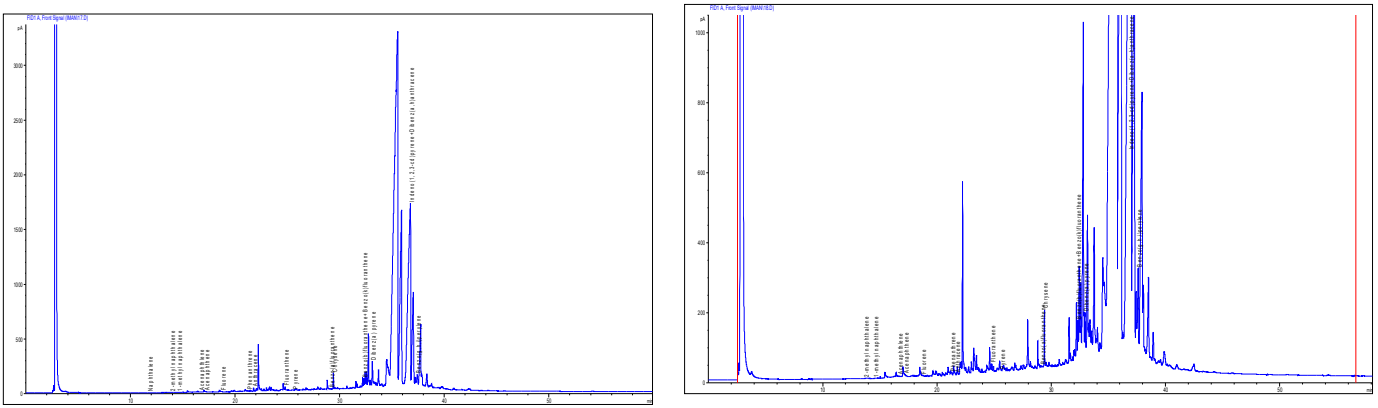

Winter season

\section{Spring season}

(Fig.9) :Chromatograms of PAHs compounds in B.bengalensis samples of the studied stations during the season 


\section{Conclusion:}

Water and 4 species of Mollusca have some concentrations of Polycyclic Aromatic hydrocarbons.

The Highest concentration of PAHs in the four species were arranged as fellow :Bellamya bengalensis $>$ Melanopsis nodosa $>$ Melanoides taberculata $>$ Theodoxus Jordani.

The sources of PAHs came from many sources, and there is seasonal variations of PAHs in the water due to many factor such as Temperature, photooxidation and bacterial degradation.

\section{Acknowledgments}

The authors wishes to thank the Marine Science Center, University of Basrah for carrying out samples analysis

\section{References}

1. Wake, H. (2005). Oil refineries: a review of their ecological impacts on the aquatic environment. Estuarine, Coastal and Shelf Science, 62(1-2), 131-140.

2. Feldstein, T., Kashman, Y., Abelson, A., Fishelson, L., Mokady, O., Bresler, V., \& Erel, Y. (2003). Marine molluscs in environmental monitoring. Helgoland Marine Research, 57(3), 212.

3. Al-Hejuje, M. M., Hussain, N. A., \& Al-Saad, H. T. (2015). Total Petroleum Hydrocarbons (TPHs) n-alkanes and Polynuclear Aromatic Hydrocarbons (PAHs) in water of Shatt AlArab River-part 1. Global Journal of Biology Agriculture and Health Sciences N, 4, 88-94.

4. Cajaraville, M.P., Robledo, Y., Etxeberria, M. and Marigomez, J. (1995). Cellular biomarkers as useful tools in the biological monitoring of environmental pollution: Molluscs digestive lysosomes. In: Cell biology in the environmental toxicology M. P. Cajaraville (ed .) Univ. of the Basque Country Press, Service, Bilbo, 29-55.

5. Cripps, G.C. and Priddle, J. 1995. Hydrocarbons content of an Antarctic in faunal bivalve-historical record or life cycle changes? Antarctic Science, 7(2): 127-136

6. Abdel-Shafy, H. I., \& Mansour, M. S. (2016). A review on polycyclic aromatic hydrocarbons: source, environmental impact, effect on human health and remediation. Egyptian Journal of Petroleum, 25(1), 107123

7. Lamichhane, S., Krishna, K. B., \& Sarukkalige, R. (2016). Polycyclic aromatic hydrocarbons (PAHs) removal by sorption: a review. Chemosphere, 148, 336-353.

8. Onozato, M., Nishigaki, A., \& Okoshi, K. (2016). Polycyclic aromatic hydrocarbons in sediments and bivalves on the Pacific coast of Japan: influence of tsunami and fire. PloS one, 11(5), e0156447.

9. Motelay-Massei A., Ollivon D., Garban B., Teil M.J., Blanchard M., Chevreuil M. (2004): Distribution and spatial trends of PAHs and PCBs in soils in the Seine River basin, France. Chemosphere, 55: 555-565

10. Peng C., Wang M., Zhao Y., Chen W. (2016): Distribution and risks of polycyclic aromatic hydrocarbons in suburban and rural soils of Beijing with various land uses, Environmental Monitoring and Assessment, 188: 162

11. Irwin RJ, editor. (1997)Environmental contaminants encyclopedia. Colorado: National Park Service.

12. Wild, S.R.; Jones, K.C. (1995) Polynuclear aromatic hydrocarbons in the United Kingdom environment: A preliminary source inventory and budget. Environ. Pollut., 88, 91-108. [CrossRef]

13. Wania, F.; Mackay, D. (1996)Tracking the distribution of persistent organic pollutants. Environ. Sci. Technol., 30, 390-396. [CrossRef] [PubMed]

14. Van Jaarsveld, J.A.; Van Pul, W.A.J.; De Leeuw, F.A. (1997)Modelling transport and deposition of persistent organic pollutants in the European region. Atmos. Environ., 31, 1011-1024. [CrossRef]

15. Li, H., \& Ran, Y. (2012). Distribution and bioconcentration of polycyclic aromatic hydrocarbons in surface water and fishes. The Scientific World Journal.

16. Ali, W.A.; Farid, W. A. and Al-Eed, A. A. (2013). Hydrocarbons distribution in Shatt Al-Arab River bacteria and fungi. International Journal of Science and Modern Engineering (IJISME), 1(12): 5-9.

17. Al-Saad, H. T., Farid, W. A., \& Al-Adhub, A. Y. (2011). Distribution and seasonal variations of n-alkanes in some species of molluscs from Shatt Al-Arab river. Mesopotamian Journal of Marine Science, 26(2), 182196

18. Abdulla SS. (1990).An investigation to river load of Shatt al-Arab in Basrah [dissertation]. Basrah: Marine Science Center, Basrah University;

19. Moyel, M.S. (2014) Assessment of water quality of the Shatt al-Arab River, using multivariate statistical technique. Mesopotomia Environ J; 1(1): 39- 46

20. UNEP (United Nation Environmental Program) (1989). Comparative toxicity test of water accommodated fraction of oils and oil dispersant's to marine organisms. Reference methods for marine pollution. No. 45, 21p

21.Grimalt, J.O. and Oliver, J. 1993. Source input elucidation in aquatic systems by factor and principal component analysis of molecular marker data. Analaytical. Chemical Acta., 278: pp. 159-176.

22.Al-Saad, H.T. (1995). Distribution and sources of hydrocarbons in Shatt Al- Arab estuary and N.W. Arabian Gulf. Ph.D. thesis, Basrah University., 186 p. 
23.Al-Mahmood, H. K. (2009). The monthly variations of discharge and effect that on a total dissolve suspended and salinity in Shatt Al-Arab River (South of Iraq). Iraqi Journal of science, 50(3), 355-368.

24.Mouillote, D.; Gaillard, S.; Aliaume, C.; Veriaque, M.; Belsher, T.; Troussellier, M. and Chi, T.D. (2005). Ability of taxonomic diversity indices to discriminate coastal Lagoon environments based on macrophytes communities. Ecological Indicators, 5(1): 1-17.

25.Rubio-Arias H, Ochoa-Rivero JM, Quintana RM, Saucedo-Teran R, Ortize-Delgado RC, Rey-Burciaga NI, et al.(2013) Development of water quality index (WQI) of an artificial aquatic ecosystem in Mexico. J Environ Prot; 4: 1296-306

26.Dojlido, J.R. and Best, G.A.( 1993) Chemistry of water and water pollution. New York: Ellis Horwood Limited;

27.Al-Hejuje, M. M. (2014). Application of water quality and pollution indices to evaluate the water and sediments status in the middle part of Shatt Al-Arab River (Doctoral dissertation, Ph. D. Thesis, Biology Department, College of Science, University of Basrah).

28.Wetzel, R.G. (2001). Limnology, lake and river ecosystems. th ed. Academic press, an Elsevier Science imprint, San Francisco, New York, London

29.Moyel, M. S., \& Hussain, N. A. (2015). Water quality assessment of the Shatt al-Arab river, Southern Iraq. Journal of coastal life medicine, 3(6), 459-465.

30.Prathumratana, L., Sthiannopkao, S., \& Kim, K. W. (2008). The relationship of climatic and hydrological parameters to surface water quality in the lower Mekong River. Environment international, 34(6), 860-866.

31.Edokpayi, J., Odiyo, J., Popoola, O., \& Msagati, T. (2016). Determination and distribution of polycyclic aromatic hydrocarbons in rivers, sediments and wastewater effluents in Vhembe District, South Africa. International journal of environmental research and public health, 13(4), 387.

32.Al-Khatib, F.M. (2008). Determination the concentrations, origin and distribution of hydrocarbon compounds in water, sediments and some biota of Hor Al-Howaiza, south of Iraq and their sources. Ph.D. Thesis., University of Basrah, College of Science, Biology Department, 228p. (In Arabic)

33.Al-Timari, A.A.K.; Hantoush, A.A. and Nasir, A.M. (2003). Petroleum hydrocarbons in southern of Iraq waters. Marina Mesopotamica, 18(2): 141-149

34.Al-Saad, H.T. (1998). Petroleum hydrocarbon concentration and n-alkanes in water from Shatt Al-Arab River. Marine Science Centre Report

35.Al-Timari, A.A.K. (2000). Oil Pollution in Shatt Al-Arab water studying the monthly variation of poly cyclic Aromatic hydrocarbons (PAHs). Marina Mesopotamica, 15(2): 535-548

36. Zakaria, M.P.; Mahat, A.A. (2006) Distribution of polycyclic aromatic hydrocarbon (PAHs) in sediments in the Langat Estuary. Costal Mar. Sci., 30, 387-395.

37. Dickhut, R.M.; Canuel, E.A.; Gustafson, K.E.; Liu, K.; Arzayus, K.M.; Walker, S.E.; Edgecombe, G.; Gaylor, M.O.; Macdonald, E.H.( 2000) Automotive sources of carcinogenic polycyclic aromatic hydrocarbons associated with particulate matter in the Chesapeake Bay region. Environ. Sci. Technol., 34, 4635-4640

38. Neff, M. (1979)Polycyclic Aromatic Hydrocarbons in the Aquatic Environment: Sources, Fates and Biological Effects; Applied Science Publishers: London, UK,

39. Eisler, R. (1987). Polycyclic aromatic hydrocarbon hazards to fish, wildlife, and invertebrates: a synoptic review. US fish and wildlife service biological report, 85(1.11), 81. 